\title{
Factors Influencing The Demand For Credit By The Private Sector In Kenya
}

\author{
Sarah Chebet, MA Econs \\ Peter W Muriu, PhD \\ School of Economics, University of Nairobi
}

doi: 10.19044/esj.2016.v12n16p390 URL:http://dx.doi.org/10.19044/esj.2016.v12n16p390

\begin{abstract}
This study investigates the effects of selected macroeconomic variables on the Demand for credit by the private sector in Kenya. The study used annual time series data for the period 1980-2012. Data was obtained from Kenya National Bureau of Statistics, World Development Indicators and supplemented by Central Bank of Kenya. Using Vector Error Correction Model (VECM) methodology, the study established that; Public investment, Short term interest rate, Long term interest rate, Employment and Domestic debt have a positive effect on demand for credit by the private sector, while per capita GDP and Exchange rate have a negative effect. The policy implication of these results is that providing sound economic growth policies, a stable macroeconomic situation, policies leading to lower credit cost and greater financial liberalization would simultaneously boost lending and lower the risk of lending to the private sector.
\end{abstract}

Keywords: Private sector credit, VECM approach, crowding out

\section{Introduction}

The development of a well-functioning financial system is important in accelerating economic growth. Kenya's Vision 2030 identifies the financial Services sector as one of the country's core growth pillars through financing overall investment needs (Republic of Kenya, 2007). Further, the First Medium Term plan (MTP_1) 2008-2012 states that, a vibrant and globally competitive financial sector ensures macroeconomic stability, promote private sector development, which in turn will generate employment opportunities and reduce poverty (Republic of Kenya, 2008)

Access to credit has been used as one of the poverty alleviation strategies as this gained momentum upon the adoption of Millennium Development Goals (MDGs) by the UN Millennium Summit held in 2000. In this regard, credit has been used as an economic tool over time with the 
aim of addressing poverty challenges. For sustainable economic growth to be achieved, improved access to finance is necessary to reduce income inequality and thereby enable low-income households, to escape from poverty (Ayenew and Zewdie, 2010).

The decision of the firms and consumers to enter the debt market in any country is dependent on demand as well as supply factors (Chen and Chivakul, 2008). On the side of demand, the desire of consumers to borrow determines their probability of engagement in the credit market. On the hand of supply, the decision on whether and how much to lend depends on the repayment capacity of the borrowers (Ibid). This study focuses on the demand side (credit demand).

The information regarding the reliability and solvency of the borrower drives the financial system (USAID, 2008). Imperfect information on interest rates charges in a loans market has direct impact on the riskiness of loans especially with regard to borrowers' adverse selection or investment actions (Stigliz and Weiss, 1981). Therefore, such information asymmetries limit the efficiency and effectiveness of the financial sector hence the need for government intervention to regulate the sector.

Kenya banking sector recorded an expansion in total credit by $8.4 \%$ to Ksh 1,765.5 billion in 2012 up from Ksh 1,628.0 billion in 2011(Republic of Kenya, 2013). The public sector credit increased by 33.6\% in 2012, with the central government including commercial bank's investment in government securities reversing the trend from a decline of $9.4 \%$ in 2011 to an increase of $30.9 \%$ in 2012 . The increase was occasioned partly by the financing need in preparation for the 2013 general elections (ibid). Growth in the share of commercial banks credit given to the private sector recorded a decline from $73.5 \%$ in 2011 to $55.2 \%$ in 2012. The decline was in line with efforts to lower inflation at the beginning of the year (Republic of Kenya, 2013).

Figure 1 shows that Kenya's private sector credit increased in 19821992 from $29.48 \%$ to $34.84 \%$ except in 1987 when there was a decline from $30.83 \%$ to $28.95 \%$. The period between 1993 and 1999 experienced fluctuations ranging from approximately $26 \%$ - 29\% except 1995 with an outstanding percentage of $34.55 \%$. The increase was attributed to the implementation of structural adjustment programs (SAP) through successful monetary and fiscal policy initiatives (1993-1995) that stabilized prices, interest rates and foreign exchange (Gouled and Adde, 1996). 
Figure 1: Trend of domestic credit to the private sector (1980-2012)

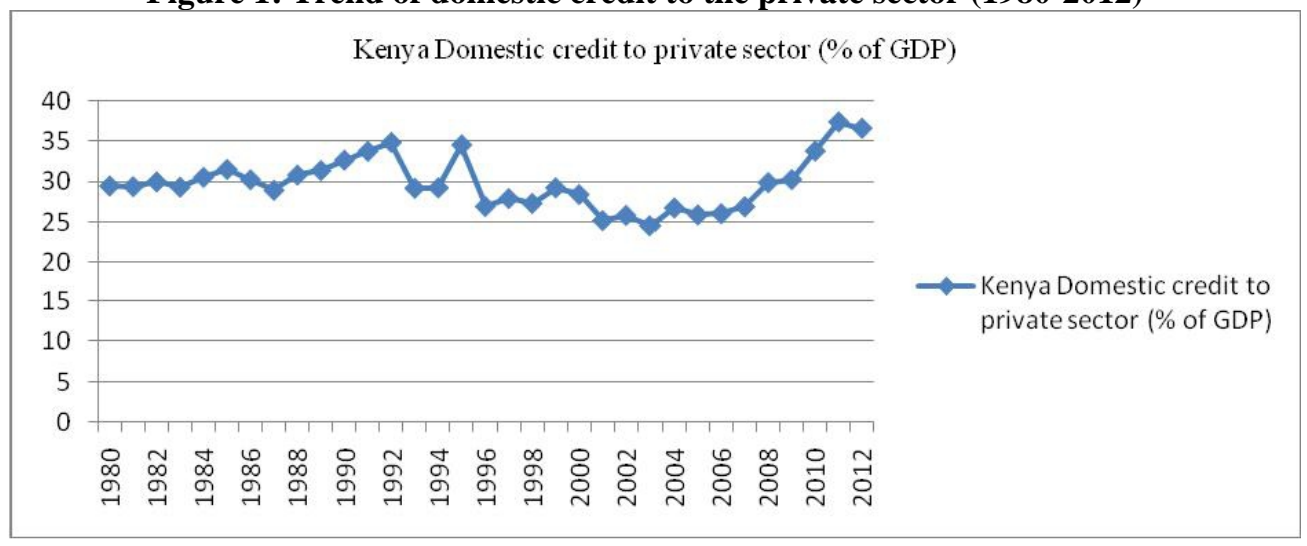

Source: World Development Indicators.

Private sector credit declined from $28.43 \%$ in 2000 to $24.60 \%$ in 2003 as a result of uncertainty surrounding the 2002 elections and inflation which rose from $1.9 \%$ in 2002 to $9.8 \%$ in 2003 ( CBK, 2003; Mwega, 2010). Generally, there was an increase in private sector credit from 2004 to 2012. The shortfall in 2012 was due to tight monetary policy that was implemented in the fourth quarter of 2011 to the first half of 2012 to address inflationary pressures and to stabilize the exchange rate (Republic of Kenya, 2012). The shortfall in credit expansion impacted negatively on economic growth.

Theoretically, the adoption of new innovations and policy developments in the financial sector is expected to create a conducive environment for borrowers hence increase the demand for credit by the private sector. Though the sector has realized changes since the initiation of reforms, the demand has not been realized as depicted by fluctuations and especially the decline in demand in 2012.

Despite the increased number of financial institutions, credit rationing through interest rates has excluded most people especially the disadvantaged individuals as they cannot bear high cost of borrowings. As a result, most individuals rely on the informal credit facilities from ASCAs and money lenders to enable them smooth their consumption behavior. A number of studies have analyzed the relationship between demand for credit and real output, interest rates, inflation and exchange rate as explanatory variables (Calza et al, 2001, Calza et al, 2003, Hofmann, 2001, Kiss, Nagy \& Vonnak, 2006, Guo and Stepanyan, 2011). These studies found that the key determinants of private sector credit are; GDP, inflation, both short and longterm interest rates and exchange rates.

The main aim of this paper is therefore to investigate the effect of Public investment and Employment on the demand for credit by private 
sector in Kenya. Specifically, the study sort to determine the effect of; GDP per capita, Public investments, Short term interest rate, Long term interest rate, Exchange rate, Employment, and Domestic debt on the demand for credit by the private sector.

Empirical strategy

\section{Model Specification}

This study adopts Calza et al. (2001) model augmented with additional control variables specified as follows;

DCPS $=f($ GDPPGR, PUBINV, SINTR, LINTR, EXR, EMP, DDEB, $\varepsilon t)$

Where,

DCPS $=$ Demand for credit by the private sector (\% of GDP)

GDPPGR $=$ GDP per capita growth rate

PUBINV=Public Investment

SINTR=Real short-term Interest rate (Treasury bill)

LINTR $=$ Real long-term interest rate (Bonds)

$\mathrm{EXR}=$ Exchange rate

$\mathrm{EMP}=$ Employment

$\mathrm{DDEB}=$ Domestic debt

This study adopts a multiplicative model specified as follows:

DCPS $=\beta_{0}$ GDPPGR $\beta_{1} *$ PUBINV ${ }_{2} *$ SINTR $\beta_{3} *$ LINTR $\beta_{4} *$ SAV $*$ EXR $\beta_{5}$ *EMP *DDEB $\beta_{7}$

Et............................................. (2)

Assuming that credit to the private sector is a function of a set of deterministic explanatory variables, equation 2 becomes:

DCPS $=\beta_{0}+\beta_{1}$ GDPPGR $+\beta_{2}$ LNPUBINV $+\beta_{3}$ SINT $+\beta 4$ LINTR $+\beta_{5}$ LNEXR $+\beta_{6} \mathrm{~L}$ $\mathrm{NEMP}+\beta_{7} \mathrm{LNDDEB}+\varepsilon_{\mathrm{t}}$

Where,

DCPS $=$ Demand for credit by the private sector (\% of GDP)

GDPPGR = GDP per capita growth rate

LNPUBINV=Logarithm of public investment

SINTR $=$ Real S-T Interest rate

LINTR $=$ Real L-T interest rate

LNEXR $=$ Logarithm of exchange rate

LNEMP $=$ Logarithm of employment

LNDDEB $=$ Logarithm of domestic debt

$\beta_{0}$ : intercept

$\beta_{1}-\beta_{7}$ : parameters

$\varepsilon_{t}:$ error term. 
Definition and measurement of variables

GDP per capita

A growing economy is able to attract investors who foresee prospects of higher revenues/profits in the future. Output growth increases consumption demand and savings coming into the financial system which will allow it to extend credit. According to Harrod-Domar, natural rate of growth depends on the increase in labour force in the absence of technological change, while warranted rate of growth depends on the savings and investment habits of households and firms. Under the standard neoclassical conditions, output is produced by labour and capital (Solow, 1956). Part of this output is consumed and the rest is saved and invested. The increase in capital stock increases net investment which stimulates the demand for credit. Therefore GDP is expected to have a positive coefficient $\left(\beta_{1}>0\right)$.

\section{Public investment}

According to the poverty impact of Public investment theory, Public investment and Private investment are complements. Increase in public capital stock raises the productivity of factors of production and hence aggregate output (Anderson, de Renzio, and Levy, 2006). In a situation of competitive labour markets and inelastic labour supply, high productivity may push up real wages, savings and investments (Ibid). Increase in investment, calls for more demand for credit especially if the return to private investment is high. Public investment is therefore expected to positively influence demand for credit $\left(\beta_{2}>0\right)$.

\section{Short-term interest rate}

This is the interest rates on debt with a maturity period of less than one year, issued by a national government through the Central Bank of Kenya as a primary instrument for regulating money supply and raising funds through open market operations i.e treasury bills. According to the expectations theory of the term structure of interest rates, the yields on financial assets of different maturities (terms) are related primarily by market expectations of future yields (Russell, 1992). When Short-term interest rates are relatively high, the yield curve is often downward-sloping; when shortterm rates are relatively low, the curve is often steeply upward-sloping (ibid).

Treasury products are sold to the highest bidder whether at the initial auction or on the secondary market. When the demand for treasury bills is high, investors bid at or above the face value. In this case, the yield will be low consistent with lower risk. Treasury rates fall during the recession phase of the business cycle and as a result, will drive bank lending rates, and all other interest rates down. Investors get attracted by low interest which 
implies higher demand for credit to finance their investments. Therefore Short-term interest rate is expected to negatively influence the demand for credit $\left(\beta_{3}<0\right)$.

\section{Long-term interest rate}

Investing in Long-term securities expose lenders to uncertainties about future returns. According to the expectations theory, the interest risk on securities tends to increase with their terms (Russell, 1992). If the risk capital loss on securities tends to increase in proportion to their remaining terms, lenders demand more interest compensation on Long-term securities than on short term securities (ibid). This will tend to make the yield curve upward-sloping.

In addition, the face value of a long-term loan compared to that of a short-term loan, is more vulnerable to the effects of inflation. Therefore, the longer the borrower has to repay the loan, the more interest the lender should receive. High interest rate increases the cost of borrowing, which discourages borrowers and eventually lowers investments. Long-term interest rate therefore is expected to affect the demand for credit by the private sector negatively $(\beta 4<0)$.

\section{Exchange rate}

Exchange rate is the price of the domestic currency for another of a different country. It is an important variable determining the capital account since Kenya is overly dependent on imported capital and intermediate imported inputs. Some lending is provided in foreign currency. This makes the credit portfolio more sensitive to exchange rate volatility. The rate of exchange between currencies keep changing from time to time due to the need for international payments in respect to trade among countries, movement of capital and interest rate repayment. Exchange rate appreciation increases the return on investment production for export, while exchange rate depreciation reduces the return on investment which therefore affects the demand for credit.

Bank lending may also be controlled by the pegged or floating exchange rates. During restriction of credit, pegged exchange rate with exchange controls over all private capital flows to be used in order to reduce the tendency of unsatisfied borrowers to turn to foreign sources of capital (Black, 1984). A floating exchange rate would generate substantial upward pressure on the exchange rate during restrictive periods, followed by downward pressure during expansionary periods. Therefore we expect an indeterminate relationship between Exchange rate and Demand for private sector credit. $\left(\beta_{5 \pm 0) \text {. }}\right.$ 


\section{Employment}

This variable represents a good proxy for wealth effect, given that it accounts for population capacity to attract credit but also the saturation effect. Second, most of the Kenyans work force is employed in the private sector. The main driver of Employment is the pace of economic growth driven by the level of investment. According to the general theory of employment, interest and money; when employment increases, aggregate real income also increases (Keynes, 1936). When aggregate real income is increased, aggregate consumption is increased, but at a lower rate than income. The excess of consumption is devoted to investment when Employment is at the given level. Given the propensity to consume, the equilibrium level of employment depends on the amount of current investment (ibid). Investment allows the entrepreneur acquire assets which can be used as collateral to borrow loans. Therefore the Employment is expected to have a positive influence on the Demand for credit $\left(B_{6}>0\right)$

\section{Domestic debt}

Domestic debt is a fundamental tool used by the governments in both developed and less developed countries to finance internal and external gaps. In Kenya domestic debt is defined as the central government debt incurred internally through borrowing in the local currency from residents. Government domestic borrowing comprises of government securities (treasury bills, treasury bonds and long-term stocks), overdraft at the Central Bank of Kenya and advances from commercial banks. (Maana, Owino and Mutai, 2008)

If the government borrows heavily from the domestic market, a shortage of funds arises prompted by increased demand for investible funds. This drives interest rates up leading to the reduction of private borrowing and hence limiting private investment and therefore crowding-out of private sector arises (Drazen, 1996). Domestic borrowing is therefore expected to have a negative effect on the Demand for credit by the private investors as a result of higher interest rates $\left(\beta_{7}<0\right)$.

Table 1: Summary of variables and measurement

\begin{tabular}{|c|c|c|c|}
\hline $\begin{array}{c}\text { Variable } \\
\text { credit }\end{array}$ & Notation & Predicted Effect & Definition \\
\hline $\begin{array}{c}\text { GDP per capita } \\
\text { growth rate }\end{array}$ & GDPPGR & Positive & $\begin{array}{c}\text { Total amount of credit borrowed } \\
\text { by the private sector }\end{array}$ \\
$\begin{array}{c}\text { Measure of the size of an } \\
\text { economy adjusted for price } \\
\text { changes and inflation. It measures } \\
\text { in constant local prices the output } \\
\text { of final goods and services and } \\
\text { incomes within an economy }\end{array}$ \\
\hline
\end{tabular}




\begin{tabular}{|c|c|c|c|}
\hline Public Investment & PUBINV & Positive & $\begin{array}{c}\text { Central government development } \\
\text { expenditure } \\
\text { (actual values) }\end{array}$ \\
\hline S-T interest rates & SINTR & Negative & $\begin{array}{c}\text { Short term market interest rates on } \\
\text { 91-day treasury bill }\end{array}$ \\
\hline L-T Interest rate & LINTR & Negative & $\begin{array}{c}\text { Long term market interest rates on } \\
\text { bond }\end{array}$ \\
\hline Exchange rate & EXR & Indeterminate & $\begin{array}{c}\text { Measure of competitiveness of the } \\
\text { local currency against the major } \\
\text { trading currencies (weighted } \\
\text { exchange rate index) }\end{array}$ \\
\hline Employment & EMP & Positive & $\begin{array}{c}\text { Total number of employed } \\
\text { persons (both in the modern and } \\
\text { informal sectors) }\end{array}$ \\
\hline Domestic debt & DDEB & Negative & $\begin{array}{c}\text { Central government debt incurred } \\
\text { internally through borrowing in the } \\
\text { local currency from residents }\end{array}$ \\
\hline
\end{tabular}

\section{Data Sources}

To achieve the objectives of this study, secondary annual time series covering the period 1980-2012 was used. Data on the dependent variable (Demand for credit by the private sector) and explanatory variables; GDP per capita growth rate, public investment, short term interest rate, long term interest rate, exchange rate, employment and domestic debt) were obtained from various issues of economic survey published by Kenya National Bureau of Statistics, World Development Indicators and supplemented by database of the Central Bank of Kenya.

Econometric approach

Time series properties of the variables and their co-integration characteristics were tested before the estimation of Equations 3. To explain the effects of determinants on demand for credit by the private sector in Kenya, the study used the ordinary least squares model (OLS).

\section{Stationarity test}

Given that most macroeconomic time-series data are non-stationary, estimates of such variables may lead to spurious regression and their economic interpretation will not be meaningful. With this regard, Unit root tests are used to test for stationary or order of integration of each series of the variables. To carry out this, Augmented Dickey Fuller (ADF) test (Dickey and Fuller, 1979) were carried out.

\section{Co-integration test}

Cointegration tests are conducted in case of non-stationarity of the series to ensure long run relationships. The long run equilibrium relationship 
among the variables was tested by least squares method. Augmented Dickey Fuller (ADF) was used to test for the stationarity of the residual and to determine if the long run model was spurious or not. Estimation of the short run model was done where the residual obtained from the long run estimation was taken as the valid error-correction term which was then built into an Error-Correction Model (ECM).

\section{Diagnostic test}

Residual diagnostic tests include normality test to check whether the error term was normally distributed, Heteroskedasticity to check whether the variance of the residuals was constant and serial correlation to check whether the error terms from different time periods were correlated.

\section{Empirical findings}

\section{Univariate analysis}

Variability of the data can be measured by Standard deviation and range. Standard deviation measures dispersion of the data from the mean. The smaller the standard deviation, the closer the scores are and the larger the standard deviation the more the scores are spread out. Table 2 shows that the deviations fall between 0.07 and 3.23. This is an indication that the series are normally distributed. Range measures the difference between the maximum and the minimum data. Like standard deviation, the larger the range, the more the data are spread out and the smaller the range the closer the data. The range lies between 0.31 and 12.78 implying that the data are fairly distributed. Jarque-Bera test shows normal distribution of the variables. Mean is a measure of central tendency and is useful in describing the data. However it is affected by extreme values making it less reliable representative of the data. Across the variables, mean values are less inflated indicating normal distribution of the data.

Table 2: Summary statistics

\begin{tabular}{|c|c|c|c|c|c|c|c|c|}
\hline & DCPS & GDPPGR & LNPUBINV & SINTR & LINTR & LNEXR & LNEMP & LNDDEB \\
\hline Mean & 29.8592 & 0.3806 & 24.1097 & -0.0072 & 0.0850 & 5.7030 & 16.4253 & 24.0934 \\
\hline Median & 29.4022 & 0.6522 & 24.0065 & -0.0070 & 0.0500 & 6.0399 & 16.6670 & 24.1467 \\
\hline Maximum & 37.3799 & 4.1739 & 26.8544 & 0.19300 & 0.3150 & 6.6258 & 18.1974 & 27.3678 \\
\hline Minimum & 24.6003 & -3.9688 & 22.2185 & -0.1160 & -0.0630 & 4.5768 & 13.99014 & 15.7818 \\
\hline Std. Dev. & 3.2284 & 2.1224 & 1.2840 & 0.0709 & 0.0937 & 0.7779 & 1.3874 & 2.9292 \\
\hline Skewness & 0.5896 & -0.1642 & 0.4258 & 0.5946 & 0.7847 & -0.2996 & -0.6422 & -1.8298 \\
\hline Kurtosis & 2.84 & 2.05 & 2.30 & 3.64 & 2.71 & 1.36 & 2.18 & 6.06 \\
\hline Jarque-Bera & 1.9460 & 1.4010 & 1.6716 & 2.5090 & 3.4986 & 4.1792 & 3.1992 & 31.2506 \\
\hline Probability & 0.3779 & 0.4963 & 0.4335 & 0.2852 & 0.1739 & 0.1237 & 0.20198 & 0.0000 \\
\hline Sum & 985.3537 & 12.5609 & 795.6215 & -0.236 & 2.8040 & 188.1999 & 542.0369 & 795.0829 \\
\hline Sum Sq. Dev. & 333.5193 & 144.1443 & 52.7588 & 0.1607 & 0.2807 & 19.3659 & 61.5989 & 274.5662 \\
\hline Obs & 33 & 33 & 33 & 33 & 33 & 33 & 33 & 33 \\
\hline
\end{tabular}




\section{Correlation}

Two variables are said to be correlated if they move together. Correlation matrix is based on the correlation coefficient ranging between -1 and +1 . Whereas correlation coefficient of -1 shows a perfect negative linear relationship between variables, +1 shows a perfect positive linear relationship, and 0 means there is no linear relationship between variables. Multicollinearity is said to occur if the correlation coefficient between two variables is above 0.7 (Gujarati, 2009).

Table 3 shows pairwise correlations amongst all the variables of interest. The results indicate that GDP per capita growth rate, Long term interest rate, Employment and Exchange rate are negatively correlated with Demand for credit by the private sector $(-0.0793,-0.045,-0.2065$ and 0.5574 respectively). Public investment, Short term interest rate and Domestic debt are positively correlated with Demand for credit by the private sector $(0.0540,0.1269$ and 0.1259 respectively). The low correlations show that there is no multicollinearity and therefore all the variables can be included in the model.

Table 3 Pair-wise Pearson Coefficient of Correlation

\begin{tabular}{|c|c|c|c|c|c|c|c|c|}
\hline & DCPS & GDPPGR & LINTR & LNDDEB & LNEMP & LNEXR & LNPUBINV & SINTR \\
\hline DCPS & 1 & -0.0793 & 0.0450 & 0.0540 & -0.2065 & -0.5574 & 0.1269 & 0.1259 \\
\hline GDPGR & -0.0793 & 1 & 0.0631 & 0.2202 & -0.0620 & -0.0271 & 0.3 & 0.3107 \\
\hline LINTR & -0.0450 & -0.0631 & 1 & 0.2174 & 0.5584 & 0.4009 & 0.1104 & 0.4439 \\
\hline LNDDEB & 0.0540 & 0.2202 & 0.2174 & 1 & 0.5454 & 0.4582 & 0.7514 & 0.1496 \\
\hline LNEMP & -0.2065 & -0.0620 & 0.5584 & 0.5454 & 1 & 0.7359 & 0.4070 & 0.1171 \\
\hline LNEXR & -0.5574 & -0.0271 & 0.4009 & 0.4582 & 0.7359 & 1 & 0.3839 & 0.0462 \\
\hline LNPUBINV & 0.1269 & 0.3256 & 0.1104 & 0.7514 & 0.4070 & 0.3839 & 1 & 0.0286 \\
\hline SINTR & 0.12593 & 0.31074 & 0.4439 & 0.1496 & 0.1171 & 0.0462 & 0.0286 & 1 \\
\hline
\end{tabular}

Heteroskedasticity test

The key assumption with regression is that the variance of the error term is homoskedastic across all the observations. Presence of heteroskedasticity has a serious consequence on ordinary least squares estimators in that they become unbiased and consistent, but they are not efficient and the standard errors are inconsistent therefore invalidating statistical test. The results given in Table 4 indicate that the $p$ value is 0.8432 i.e $84.32 \%$ which is non-significant at $5 \%$ level of significance. This is an indication that the errors are homoskedastic and independent of the regressors, therefore we accept the null hypothesis of constant variance.

Table 4: Heteroskedasticity Test: Breusch-Pagan-Godfrey

\begin{tabular}{cccc}
\hline F-statistic & 0.500584 & Prob. F(8,23) & 0.8432 \\
Obs*R-squared & 4.745456 & Prob. Chi-Square(8) & 0.7844 \\
Scaled explained SS & 2.176660 & Prob. Chi-Square(8) & 0.9751 \\
\hline
\end{tabular}




\section{Autocorrelation test}

Autocorrelation (sometimes called serial correlation) occurs when one of the Gauss-Markov assumptions fails and the error terms are correlated. This can be due to a variety of problems, but the main cause is when an important variable has been omitted from the regression. To test for first order autocorrelation, we use the Durbin-Watson (DW) d statistic. Serial correlation analysis is carried out to determine autocorrelation of errors in a regression model. Presence of serial correlation between the residuals of successive years invalidates the statistical test. This calls for a test to check whether an important variable has been omitted from the model or a variable has been wrongly included in the model. Test results are given in table 5 .

Table 5: Test for Autocorrelation using DW test: Dependent Variable: RESID

\begin{tabular}{clll}
\hline F-statistic & 0.1430 & Prob. F(2,21) & 0.8676 \\
Obs*R-squared & 0.4300 & Prob. Chi-Square(2) & 0.8065 \\
Durbin-Watsostat & 2.0145 & & \\
\hline
\end{tabular}

The null hypothesis states that the residuals of Error Correction Model (ECM) are serially uncorrelated. Based on the results in Table 5, the Observed R-squared is 0.43 and the corresponding Prob. Chi- Square of $0.8065(80.7 \%)$. P-value is more than 5\% significant level and therefore we accept the null hypothesis. The DW statistic assumes a value 2.0145 indicating that the residuals from OLs regression are not autocorrelated since the DW is approximately 2.

\section{Normality test}

Test for normality is done to check whether the error term is normally distributed. The basic idea behind the Jarque-Bera test is that the normal distribution (with any mean or variance) has a skewness coefficient of zero, and a kurtosis coefficient of three-zero excess kurtosis. The results in Figure 3 indicate that skewness is -0.144 , kurtosis is 2.7758 and Jarque-Bera test statistic is 0.1777 . 
Figure 3: Graphical representation of normality Test

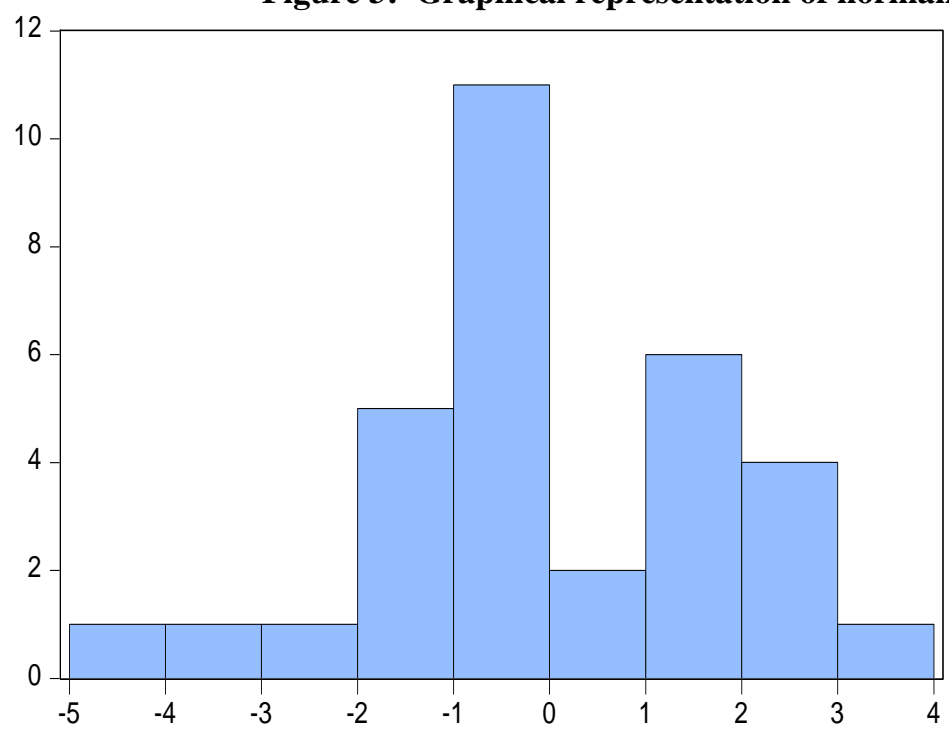

$\begin{array}{lc}\text { Series: Residuals } \\ \text { Sample 1981 } 2012 \\ \text { Observations } 32 \\ \text { Mean } & 1.21 \mathrm{e}-16 \\ \text { Median } & -0.184458 \\ \text { Maximum } & 3.922062 \\ \text { Minimum } & -4.180745 \\ \text { Std. Dev. } & 1.859203 \\ \text { Skewness } & -0.144026 \\ \text { Kurtosis } & 2.775771 \\ & \\ \text { Jarque-Bera } & 0.177670 \\ \text { Probability } & 0.914996\end{array}$

The probability value for the Jarque-Bera test is 0.91 or $91 \%$ which is greater than 5 percent significant level. A sufficiently large value of JarqueBera test will lead us to reject the null hypothesis that the errors are normally distributed.

Graphical illustrations in Figure 2 present the time series behaviour of the variables described in the summary statistics over time. A causal inspection of the graphs shows that the nature of the time series under study varies. All the variables with the exception of GDP per capita and short-term interest rate are trending and therefore non-stationary. 
Figure 2: Time series trend of the variables

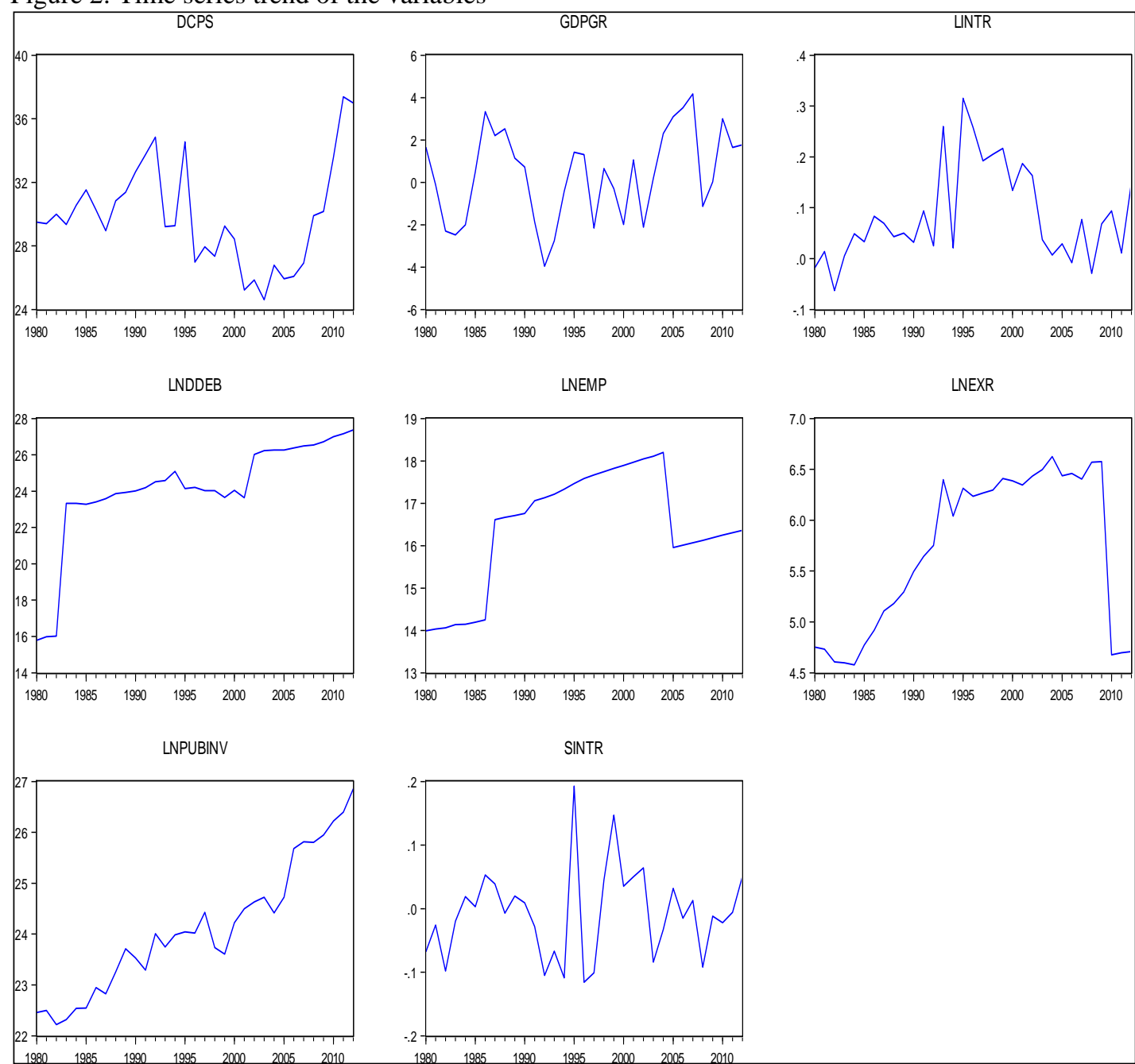

Stationarity test

As an essential step of multiple linear regressions, Augmented Dickey-Fuller (ADF) $(1979,1981)$ test has been applied. It is based on the simple logic that non-stationary process has infinite memory as it does not show decay in a shock that takes place in the process. Unit root test was done to check for stationarity of the variables. Decision rule is based on the null hypothesis that the variable has a unit root (non stationary) against alternative hypothesis that the variable has no unit root (stationary). Test for individual variable stationarity helps to establish whether the variables are I(0) or I(1). To ascertain this, the study utilized the Augmented Dickey Fuller Test. Decision is reached by comparing the ADF test statistic with critical values at $5 \%$ level. 
The results in Table 6 indicate that the series: demand for credit by the private sector, public investment, long term interest rate, exchange rate, employment and domestic debt are non-stationary while GDP per capita and short term interest rate are stationary at levels. Regression analysis of non stationary variables yields spurious regression results. This therefore calls for first differencing of the non-stationary variables. Hypothesis testing in economic analysis seeks to establish the significance of the beta coefficients in explaining the dependent variables. In this case, the beta coefficients generated from regressing private sector credit on non stationary variables will lead to wrong inferences. This is because the hypothesis test (t-statistic) is a function of the beta coefficient and the standard errors.

All variables except GDP per capita and Short term interest rate are non stationary at levels. Differencing is done to check if the non stationary variables will be made stationary. As indicated in the results, non stationary variables are integrated of order one (I (1)) implying that they become stationary after differencing once. The only problem associated with differencing variables is that there is loss of long run time series properties. However, the error correction model helps in recovering the lost properties through the error correction term generated from the short-run estimation.

Table 6: Unit root tests

\begin{tabular}{|c|c|c|c|c|c|c|c|c|c|}
\hline & \multicolumn{4}{|c|}{ At levels } & \multicolumn{4}{|c|}{$1^{\text {st }}$ difference } & \multirow{3}{*}{$\begin{array}{l}\text { Order of } \\
\text { integration }\end{array}$} \\
\hline & \multicolumn{2}{|c|}{ Constant } & \multicolumn{2}{|c|}{ Trend \& Intercept } & \multicolumn{2}{|c|}{ Constant } & \multicolumn{2}{|c|}{ Trend \& Intercept } & \\
\hline & t-stat & $\begin{array}{c}5 \% \\
\text { Critical } \\
\text { value }\end{array}$ & t-stat & $\begin{array}{c}5 \% \\
\text { Critical } \\
\text { value }\end{array}$ & t-stat & $\begin{array}{c}5 \% \\
\text { Critical } \\
\text { value }\end{array}$ & t-stat & $\begin{array}{c}5 \% \\
\text { Critical } \\
\text { value }\end{array}$ & \\
\hline DCPS & -1.7027 & -2.9571 & -1.5615 & -3.5578 & -6.8910 & -2.9604 & -7.0114 & -3.5629 & $\mathrm{I}(1)$ \\
\hline GDPPGR & $-3.1496^{* *}$ & -2.9571 & - & - & - & - & - & - & $\mathrm{I}(0)$ \\
\hline LNPUBINV & 0.3312 & -2.9571 & -2.4889 & -3.5578 & $-5.7480 * *$ & -2.9640 & $-5.8829 * *$ & -3.5684 & $\mathrm{I}(1)$ \\
\hline SINTR & $-5.4975 * *$ & -2.9571 & - & - & - & - & - & - & $\mathrm{I}(0)$ \\
\hline LINTR & -1.7608 & -2.9604 & -1.6572 & -3.5629 & $-11.818^{* *}$ & -2.9604 & $-11.6664 * *$ & -3.5629 & $\mathrm{I}(1)$ \\
\hline LNEXR & -1.3795 & -2.9571 & -0.4386 & -3.5578 & $-5.6462 *$ & -2.9604 & $-6.1842 * *$ & -3.5628 & $\mathrm{I}(1)$ \\
\hline LNEMP & -1.8974 & -2.9571 & -1.3284 & -3.5578 & $-5.4226^{* *}$ & -2.9604 & $-5.7196^{* *}$ & -3.5629 & $\mathrm{I}(1)$ \\
\hline LNDDEB & -2.9814 & -2.9571 & -3.2221 & -3.5578 & $-5.8609 * *$ & -2.9604 & $-6.1098 * *$ & -3.5629 & $\mathrm{I}(1)$ \\
\hline
\end{tabular}

Note: The $1 \%, 5 \%$ and $10 \%$ significant level is denoted by $* * *$ and $* * *$ respectively.

\section{Co-integration test}

Many time series are in an equilibrium relationship over time, what we call co-integration. Co-integration analysis was done on non-stationary time series variables to test stationary linear relationship between them. Cointegration exists between two non-stationary series if they possess the same order of integration and a linear combination of them becomes stationary. Before running the co-integration test, we need to determine the optimal lag length to use in running our models. A summary of optimal lag length selection is given in Table 7 . 
Table 7:VAR Lag Length Selection

\begin{tabular}{ccccccc}
\hline \hline Lag & LogL & LR & FPE & AIC & SC & HQ \\
\hline \hline 0 & -225.9075 & NA & 0.000494 & 15.09081 & 15.46087 & 15.21144 \\
1 & -90.29239 & $192.4860^{*}$ & $5.59 \mathrm{e}-06$ & 10.47048 & $13.80103^{*}$ & 11.55615 \\
2 & -5.807671 & 76.30878 & $3.84 \mathrm{e}-06^{*}$ & $9.148882^{*}$ & 15.43992 & $11.19960^{*}$ \\
\hline \hline
\end{tabular}

* indicates lag order selected by the criterion

LR: sequential modified LR test statistic (each test at 5\% level)

FPE: Final prediction error

AIC: Akaike information criterion

SC: Schwarz information criterion

HQ: Hannan-Quinn information criterion

According to AIC selection criterion, the lower the test statistic, the better the model. As a result this selection criterion recommends 2 lags as the optimal lag length. Adopting this criterion, this study uses optimum lag of 2 . Since the test results show that some series are integrated, we run a regression using Johansen co-integration test approach to establish the linear co-integration of variables. Test results given in Table 8 .

Table 8: Johansen Co-integration Test

Unrestricted Co-integration Rank Test (Trace)

\begin{tabular}{ccccc}
\hline \hline $\begin{array}{c}\text { Hypothesized } \\
\text { No. of CE(s) }\end{array}$ & Eigenvalue & $\begin{array}{c}\text { Trace } \\
\text { Statistic }\end{array}$ & $\begin{array}{c}0.05 \\
\text { Critical Value }\end{array}$ & Prob.** \\
\hline \hline None * & 0.879387 & 216.7577 & 159.5297 & 0.0000 \\
At most 1 & 0.843048 & 151.1876 & 125.6154 & 0.0005 \\
At most 2 & 0.654959 & 93.78141 & 95.75366 & 0.0678 \\
At most 3 & 0.503723 & 60.79452 & 69.81889 & 0.2118 \\
At most 4 & 0.447142 & 39.07529 & 47.85613 & 0.2573 \\
At most 5 & 0.320095 & 20.70303 & 29.79707 & 0.3764 \\
At most 6 & 0.242571 & 8.743184 & 15.49471 & 0.3897 \\
At most 7 & 0.004204 & 0.130600 & 3.841466 & 0.7178 \\
\hline \hline
\end{tabular}

Trace test indicates 2 co-integrating eqn(s) at the 0.05 level

* denotes rejection of the hypothesis at the 0.05 level

**MacKinnon-Haug-Michelis (1999) p-values

Unrestricted Co-integration Rank Test (Maximum Eigenvalue)

\begin{tabular}{ccccc}
\hline \hline $\begin{array}{c}\text { Hypothesized } \\
\text { No. of CE(s) }\end{array}$ & Eigenvalue & $\begin{array}{c}\text { Max-Eigen } \\
\text { Statistic }\end{array}$ & $\begin{array}{c}0.05 \\
\text { Critical Value }\end{array}$ & Prob.** \\
\hline \hline None $*$ & 0.879387 & 65.57009 & 52.36261 & 0.0014 \\
At most 1 $*$ & 0.843048 & 57.40620 & 46.23142 & 0.0022 \\
At most 2 & 0.654959 & 32.98689 & 40.07757 & 0.2520 \\
At most 3 & 0.503723 & 21.71923 & 33.87687 & 0.6293
\end{tabular}




$\begin{array}{lllll}\text { At most 4 } & 0.447142 & 18.37226 & 27.58434 & 0.4644 \\ \text { At most 5 } & 0.320095 & 11.95985 & 21.13162 & 0.5516 \\ \text { At most 6 } & 0.242571 & 8.612584 & 14.26460 & 0.3198 \\ \text { At most 7 } & 0.004204 & 0.130600 & 3.841466 & 0.7178\end{array}$

$$
\begin{aligned}
& \text { Max-eigenvalue test indicates } 2 \text { co-integrating eqn(s) at the } 0.05 \text { level } \\
& * \text { denotes rejection of the hypothesis at the } 0.05 \text { level } \\
& * * \text { MacKinnon-Haug-Michelis (1999) p-values }
\end{aligned}
$$

Table 8 shows trace statistic of 216.76 which is greater than the corresponding critical value (159.53) and p-value of zero (0), less than 5\% hence we reject the null hypothesis. The results also indicate that there is utmost one co-integrated equation with trace statistic of 151.19 greater than the corresponding critical value of 125.62 and p-value of 0.001 . This implies that we reject the null hypothesis that all the variables are co-integrated. The third hypothesis shows that there at most 2 co-integrating equations. The trace statistic is 93.78 less than critical value of 95.75 and p-value of 0.068 greater than $5 \%$. We therefore accept the null hypothesis. The decision is that there are two co-integrating equations at $5 \%$ level or all variables have long run association.

Maximum Eigenvalue results on the other hand shows that there is no co-integration among the variables. The Max-eigen statistic 65.57 is greater than the corresponding critical value 52.36 while p-value of 0.0014 is less than $5 \%$ hence we reject the null hypothesis. The results also indicate that there is utmost one co-integrated equation with Max-eigen statistic of 57.41, critical value of 46.23 and p-value of 0.002 . As a result we reject the null hypothesis since the trace statistic is greater than the critical value and $\mathrm{p}$ value is less than 5\%. The third null hypothesis suggested at most 2 cointegrating equations with Max-eigen statistic of 32.99 being less than critical value of 40.078 and p-value of 0.25 greater than $5 \%$. Therefore we accept the null hypothesis. The overall decision is that all the variables are co-integrated implying that all the variables have a long-run relationship hence we run the Vector Error Correction Model (VECM).

The VECM approach can distinguish between stationary variables with transitory (temporary) effects and non-stationary variables with permanent (persistent) effects. It also has the advantages that it can combine the long run and short run information in the data by exploiting the cointegration property of the model. We opt for the Johansen approach to alternative single equation estimators such as ARDL approach which requires one way causality co-integration, because we cannot rule out the existence of multiple long run relationships, nor do we have any a priori reason to assume that any set of variables is weakly exogenous.

The results in Table 8 shows that the variables are co-integrated and therefore the system of equation is modified to allow for the co-integrating 
relationship between the differenced variables. Introducing the co-integrating relationships leads to a Vector Error Correction Model (VECM). The estimation results are presented in Table 9.

Table 9: Vector Error Correction Estimates

\begin{tabular}{crr}
\hline \hline Cointegrating Eq: & CointEq1 & CointEq2 \\
\hline \hline DCPS(-1) & 1.000000 & 0.000000 \\
& & \\
LNPUBINV(-1) & 0.000000 & 1.000000 \\
& & \\
LINTR(-1) & 263.1462 & 25.31600 \\
& $(26.3324)$ & $(2.32589)$ \\
& {$[9.99324]$} & {$[10.8844]$} \\
& & \\
LNEXR(-1) & -14.37479 & -2.686223 \\
& $(3.41952)$ & $(0.30204)$ \\
& {$[-4.20375]$} & {$[-8.89362]$} \\
& & \\
LNEMP(-1) & -7.901045 & -0.525202 \\
& $(1.82948)$ & $(0.16159)$ \\
& {$[-4.31875]$} & {$[-3.25013]$} \\
& 11.77684 & 0.822027 \\
LNDDEB(-1) & $(0.78245)$ & $(0.06911)$ \\
& {$[15.0513]$} & {$[11.8941]$} \\
& & \\
& -127.4241 & -22.24262 \\
C & &
\end{tabular}

The results in Table 9 indicate two co-integrating equations; CointEq1 and CointEq2.

Hence the co-integrating model for DCPS is as follows:

$\mathrm{D}(\mathrm{DCPS})=\mathrm{C}(1) *(\mathrm{DCPS}(-1)+263.146150563 * \operatorname{LINTR}(-1)-$

14.3747878547*LNEXR(-1) - 7.90104542415*LNEMP(-1) +

11.7768362209*LNDDEB(-1) - 127.424079653)

\section{Empirical results and discussion}

After establishing the linear combination of the variables, a regression model capturing all variables suggested by the study to be the main determinants of private sector credit was estimated to establish the effects of the selected macroeconomic variables on demand for credit by the private sector. Estimation was done using OLS method and the results presented in Table 10. 
Table 10: Effects of the selected variables on Demand for credit by the Private sector

\begin{tabular}{|c|c|c|c|c|}
\hline Variable & Notation & Model & Notation & $\begin{array}{l}\text { Model with } \\
\text { ECM }\end{array}$ \\
\hline Constant & $\mathrm{C}$ & $\begin{array}{l}15.9279 * \\
(1.5749)\end{array}$ & $\mathrm{C}$ & $\begin{array}{c}0.378941 \\
(0.762542)\end{array}$ \\
\hline GDP per capita growth rate & GDPPGR & $\begin{array}{c}-0.4737 * * \\
(-2.0719)\end{array}$ & GDPPGR & $\begin{array}{c}-0.239858 \\
(-1.010233)\end{array}$ \\
\hline Public investment & $\begin{array}{c}\text { LNPUBIN } \\
\text { V }\end{array}$ & $\begin{array}{l}1.1170 * * \\
(2.1588)\end{array}$ & $\begin{array}{c}\text { D(LNPUBIN } \\
\text { V) }\end{array}$ & $\begin{array}{c}0.713977 \\
(0.522088)\end{array}$ \\
\hline Short term interest rate & SINTR & $\begin{array}{l}8.9472 * \\
(1.2247)\end{array}$ & SINTR & $\begin{array}{c}10.76165 \\
(1.237638)\end{array}$ \\
\hline Long term interest rate & LINTR & $\begin{array}{l}1.8057 * \\
(0.2923) \\
\end{array}$ & D(LINTR) & $\begin{array}{c}0.473712 \\
(0.075280) \\
\end{array}$ \\
\hline Exchange rate & LNEXR & $\begin{array}{c}- \\
3.9185 * * \\
* \\
(-4.9540)\end{array}$ & $\mathrm{D}(\mathrm{LNEXR})$ & $\begin{array}{l}-2.108140 \\
(-1.709613)\end{array}$ \\
\hline Employment & LNEMP & $\begin{array}{l}0.4553^{*} \\
(0.8607)\end{array}$ & $\mathrm{D}(\mathrm{LNEMP})$ & $\begin{array}{c}0.146976 \\
(0.195703)\end{array}$ \\
\hline Domestic debt & LNDDEB & $\begin{array}{l}0.0814^{*} \\
(0.3435) \\
\end{array}$ & D(LNDDEB) & $\begin{array}{c}-0.331539 \\
(-0.968951) \\
\end{array}$ \\
\hline $\begin{array}{l}\text { Error Correction Term } \\
(\mathrm{ECM})\end{array}$ & & & $\mathrm{U}(-1)$ & $\begin{array}{l}-0.457952 * \\
(-1.805206) \\
\end{array}$ \\
\hline R-squared & \multicolumn{2}{|c|}{0.593315} & $\begin{array}{l}\text { R-squared } \\
\text { Adjusted R- }\end{array}$ & 0.317572 \\
\hline Adjusted R-squared & \multicolumn{2}{|c|}{0.479444} & squared & 0.080206 \\
\hline F-statistic & \multicolumn{2}{|c|}{5.210387} & F-statistic & 1.337900 \\
\hline Prob(F-statistic) & \multicolumn{2}{|c|}{0.000925} & $\begin{array}{l}\text { Prob(F-statistic) } \\
\text { Durbin-Watson }\end{array}$ & 0.066887 \\
\hline Durbin-Watson stat & \multicolumn{2}{|c|}{1.003429} & stat & 1.880747 \\
\hline
\end{tabular}

Note: The $1 \%, 5 \%$ and $10 \%$ significant level is denoted by $* * *, * *$ and $*$ respectively. Tstatistics given in parentheses.

A lagged error correction term (ECT) was fitted to the short-run model as an explanatory variable to establish the speed of adjustment towards the equilibrium per period. The residual was taken as valid error correction term; hence the model resulted into the error correction model (ECM). The coefficient of the residual is interpreted as the speed of adjustment or the amount of disequilibrium transmitted each period to demand for credit by the private sector.

The Error Correction model regression results showed that the coefficient of the error correction term $(U(-1))$ is -0.457952 which is less than one and significant at $10 \%$. The significance implies that whenever there are deviations in the demand for private sector credit from an 
equilibrium path, the model corrects at the rate of $45.8 \%$ annually. The negative coefficient of ECT and a p- value of $0.0842(8.4 \%)$ give validity that the dependent variable and the independent variables have a long run equilibrium relationship. This suggests that in the long run, bank credit to the private sector is co-integrated with other explanatory variables across all specified models. This also reveals that the specified equations may be describing both demand and supply behavioural relationships.

The goodness- of- fit $\left(\mathrm{R}^{2}\right)$ for the short run model is 0.3176 . This indicates that $31.8 \%$ of the variance in demand for credit by the private sector is explained by the variances of independent variables. The DW statistic of 1.8807 which is greater than $\mathrm{R}^{2}$ shows that the model is not spurious, therefore we accept the model. From the estimation results, all the explanatory variables are insignificant meaning that in the short run there is no equilibrium.

In the long run, the adjusted R-squared assumes a value of 0.47944 suggesting that the data fits the statistical model well. This implies that $47.9 \%$ of the variation in the demand for private sector credit is explained by the listed explanatory variables. The F-statistic gives the joint significance of the model. The F statistic of 5.2104 with a p-value of zero indicates that jointly, the independent variables captured in the model significantly explain the changes in the demand for private sector credit. The Durbin-Watson test statistics states that the null hypothesis of the residual from an ordinary least squares regression is not autocorrelated. The results revealed a DW statistics of 1.0034 indicating that there is no problem of autocorrelation (the model is not spurious) and therefore we fail to reject the null hypothesis.

The results of the study show that per capita GDP has a negative and significant impact on demand for credit by the private sector in the long run. This was indicated by the regression coefficient of -0.4737 and a $\mathrm{P}$ - value of 0.0487. The results imply that an increase in per capita GDP by one unit leads to a decrease in demand for credit by the private sector by 0.47 . This is inconsistent with the studies done by Calza (2001) who found a positive relationship. It implies that during economic boom firms require less credit for firm growth.

Also more importantly, the results of the study indicate a positive and significant relationship between the demand for credit by the private sector and Public investment as expected. The regression coefficient of 1.1170 and a P-value 0.0407 implies that an increase in public investment by one unit leads to an increase in demand for credit by 1.12. As a result, the increased public sector investment crowds in private sector investment and increased demand for credit by the private sector in the long run. This finding supports Chibuye (2013). Short term interest rate is positive but insignificant contrary to our hypothesis and inconsistent with the results of Calza et al. (2001). The 
results also show that long term interest rate is positive and insignificant with the demand for credit by the private sector. This is contrary to our hypothesis. The finding is inconsistent with the results of Calza et al. (2001).

Another interesting finding is the negative effect of Exchange rate on the Demand for credit by the private sector which is highly significant. This implies that an increase in Exchange rates by one unit lead to a decrease in demand for credit to the private sector by 3.92. In the long run, bank credit is negatively related to exchange rate. This may be attributed to the fact some lending is provided in foreign currency which makes the credit portfolio more sensitive to exchange rate volatility. This finding is however inconsistent with Guo and Stepanyan (2011).

Employment is positive which is consistent with our hypothesis but insignificant. Domestic debt is also positive but statistically insignificant. This may be due to the fact that the government invest the borrowings in productive sectors that boosts and attract private sector investment. Previous studies (See for example Drazen, 1996) found a negative relationship between domestic debt and private borrowings.

\section{Concluding remarks}

The purpose of this study was to establish the determinants of private sector credit demand in Kenya. Using the Johansen VECM methodology, the study identified a co-integrating relationship linking credit to the private sector, per capita GDP, public investment, exchange rate, employment, domestic debt and interest rates. Across the specified models, the error term is found to have the expected negative sign and is statistically significant at $10 \%$ level. The magnitude of the speed of adjustment confirms that any deviation from the equilibrium level would be corrected relatively fast. Summary statistics indicate that with the exception of domestic debt, the rest of the variables were normally distributed. The ADF test was utilized to check for the presence of unit root.

The results indicated that per capita GDP has a negative and significant effect on demand for credit by the private sector. Higher economic growth improves the revenues for the private sector which implies lower levels of credit uptake. The estimation results also revealed that public investment significantly influences the demand for private sector credit. In the long-run, private sector credit is negatively related to exchange rate which may be attributed to the fact some credit is provided in foreign currency which makes the credit portfolio more sensitive to exchange rate volatility.

Based on the results, providing a stable macroeconomic situation, policies leading to lower credit cost and greater financial liberalization would simultaneously boost lending and lower the risk of lending to the private 
sector. Future research should distinguish between different types of lending. It may be worthwhile to categorize amongst manufacturing, trade and construction which are the main sectors affecting the credit demand. An analysis by maturities would also provide further insight about the cyclicality and elasticity behaviour of short run versus long run lending.

\section{References:}

Anderson, E., de Renzio, P. and Levy, S. (2006). The Role of Public Investment in Poverty Reduction: Theories, Evidence and Methods. Working Paper no. 263, United Kingdom

Ayenew, Z. and Zewdie, S. (2010). Do urban poor benefit from microfinance institutions? National Monthly Preferred Journal of Research in Commerce and Management, 2:57-63.

Black, S. (1984). 'Exchange Rate Theory and Practice', the Relationship between Exchange Rate Policy and Monetary Policy in Ten Industrial Countries, University of Chicago Press, United States, 499-516.

Calza, A., Gartner, C. and Sousa, J. (2001). Modeling the demand for loans to the private sector in the Euro area. European Central Bank, Working Paper No. 55, Germany.

Calza, A., Manrique, M. and Sousa, J. (2003). Aggregate loans to the Euro area private sector. European Central Bank, Working Paper No. 202, Germany.

Chibuye, K. B. (2013). Public Investment, Private Investment and Economic Growth in Zambia. Dissertation. The University of Zambia. Accessed in October, 2013: http://dspace.unza.zm:8080/xmlui/handle/123456789/2645

Chen, K. C. and Chivakul, M. (2008). What Drives Household Borrowing and Credit Constraints? Evidence from Bosnia and Herzegovina. IMF Working Paper no.08/202.

Dickey, D. A. and Fuller, W. A. (1979). Distribution of the Estimators for Autoregressive Time Series with a Unit Root. Journal of the American Statistical Association, 74:427-431.

Drazen, A. (1997). Towards a Political-Economic Theory of Domestic Debt. National Bureau of Economic Research, Working Paper no. 5890. USA.

Egert, B., Backé, P. and Zumer, T. (2006). Credit Growth in Central And Eastern Europe: New (Over) Shooting Stars?. Working Paper Series no. 687.

Guo, K. and Stepanyan, V. (2011). Determinants of Bank Credit in Emerging Market Economies. IMF Working Paper no. 11/51.

Gujarati, D.N., Porter, D.C. (2009). "Basic Econometrics," Fifth Edition, McGraw-HILL International Editions Economics Series, Singapore. 
Hofmann, B. (2001). The Determinants of Private Sector Credit in Industrialized Countries: Do property prices matter? Bank for International Settlements, Working Paper no. 108.

Keynes, J. M. (1936). The General Theory of Employment, Interest and Money. Macmillan: London.

Kiss, G., Nagy M. and Vonnak, B. (2006). Credit Growth in Central and Eastern Europe: Convergence or Boom? MNB Working Papers no. 2006/10. Maana, I., Owino R. and Mutai N. (2008). Domestic Debt and its Impact on the Economy- The Case of Kenya. Paper Presented during the $13^{\text {th }}$ Annual African Econometric Society Conference. Pretoria: South Africa.

Mwega, M. F. (2010). Global Financial Crisis Discussion Series. Paper 17: Kenya phase 2, London.

Republic of Kenya (2013). Economic Survey; Kenya national bureau of statistics. Nairobi: Government printers

Republic of Kenya (2008). First Medium Term Plan (2008-2012); Ministry of State for Planning, National Development and Vision 2030. Nairobi: Government printers.

Republic of Kenya (2007). Kenya Vision 2030; A Globally Competitive and Prosperous Kenya. Nairobi: Government printers.

Russell , S .H. (1992). Understanding the term structure of interest rates: the expectation theory. St. Louis Review, 74:36-50.

Stiglitz, J. E. and Weiss A. (1981). Credit Rationing in Markets with Imperfect Information. The American Economic Review, 71:393-410.

USAID (2008). Developing the Supply of Financial Services and Improving the Efficiency of the Banking Sector in Angola; USAID Contract No. 690-M00-04-00309-00 (GS 10F-0277P). Accessed: http://pdf.usaid.gov/pdf_docs/Pnadx263.pdf 